\title{
THE IMPACT OF A UNITARY REGULATORY AND HRM FRAMEWORK: MANAGERIAL AND WORKER VIEWS FROM THE NEW ZEALAND WORKPLACE
}

\author{
ALAN GEARE \\ IAN MCANDREW \\ FIONA EDGAR
}

University of Otago / Canada

\begin{abstract}
This study reports views of managers and workers about employment relationships and Human Resource Management (HRM) practice. Drawing on both qualitative and quantitative data collected in 2005, this paper specifically seeks to examine how a unitary legislative framework, along with the influence of HRM with its unitary underpinnings, has impacted on manager and worker views of employment relations in the New Zealand context. Data analysis revealed current views on employment relations closely paralleled the literature on best practice HRM, and insights provided by this group of managers and workers highlight what are considered to be the important employment relations issues being faced today.
\end{abstract}

Key Words: Human Resource Management, Best Practice, Ideology, Unions, Managers, Workers 


\section{INTRODUCTION}

Mainstream HRM research can be considered problematic in that it tends to consider management in a vacuum and ignore the other key players in employment relations. This is despite the fact that HRM is obviously suspicious of an employee who appears less than wholly committed to the employing organisation, and despite empirical studies showing that 'best practice' HRM in organisations is impacted by state regulation and by union presence. (Godard and Delaney, 2002). Indeed Brown, Deakin, Nash and Oxenbridge (2000: 619) point out that unions and the state are closely intertwined with respect to workplace practice:

One might therefore characterize what has been happening as a shift in workplace union activity from limiting the obligations placed on employees by employers, towards monitoring the exercise of employers' obligations towards their employees.

One of the few researchers to focus recently on the role of the state in employment relations is Roy Adams $(1989,1999,2002)$. He has highlighted (1989: 55) the significance of the state for both employer and union behaviour. Comparing the situation in the United States and Canada he observes that:

The difference in both employer behaviour and union fortunes in the two countries may be explained to a large extent by reference to labour policy. In the United States the state has gradually drawn back from it's commitment to guarantee the Labour Accord whereas the state's commitment in Canada has deepened.

Where other HRM researchers have given the state and unions some attention, they have primarily advocated that unions seek a more cooperative relationship with management, and that government pave the way for this to occur by creating conditions whereby managerial prerogative is increased, allowing HRM practices to be more easily introduced. 
Perhaps more surprising than the lack of consideration of the state and unions is the lack of employee voice in HRM research. Guest (1999:5) points out that "From its inception human resource management reflected a management agenda to the neglect of workers' concerns." Even though "one key group who can report on practice are workers on the receiving end" (Guest, 2001:1098).

Over the last few years nothing much has changed and Holgate, Hebson and McBride (2006:326) still see a need to "give voice to all workers (male and female)." Ignoring employee voice is consistent with the unitary perspective as it implies that employee views would be consistent with managerial views. Recently, in New Zealand, the state and the regulation it has imposed appears to also reflect the pursuit of a unitarist agenda which complements the objective of HRM. As observed earlier (Geare, Edgar and McAndrew, 2006:1192), "HRM sees the interests of workers and managers to be aligned and the unitary assumptions upheld." This has meant research in this area has, consistent with the unitary perspective, failed to give consideration to worker (and by extension union) interests.

This paper aims to explore the impact of a unitarist regulatory framework, along with the influence of unitarist HRM on manager and worker views about employment relationships. First, this paper offers a brief historical overview of the regulatory framework in New Zealand. Second, the objectives and uptake of HRM, with its unitary underpinnings are discussed. These two areas provide the broad context for assessing the impact of regulation and HRM on manager and worker views about current employment relationships in the New Zealand workplace.

\subsection{The New Zealand Context - A Unitary Agenda}

Anti-union ideologies, and hence anti-pluralist ideologies, have been explicit in the recent past in New Zealand's employment regulatory framework. Although New Zealand had had compulsory union membership by law or agreement since 1936, voluntary unionism was 
mandated by the Employment Contracts Act (EC Act) in 1991, as a major plank in the then conservative government's primary efforts to marginalise unions. This was tacitly admitted in a publication by the two major employer lobby groups of the time - the New Zealand Business Roundtable and the New Zealand Employers' Federation (1992). With the introduction of the EC Act, there was an immediate significant drop in union density. But longer term, the managerial opposition to unionisation legitimized by the EC Act has clearly had an impact on union consciousness in New Zealand. For example, Haynes, Boxall and Macky (2006:203) report:

... management's opposition to unions appears to influence desire for unions in New Zealand's non-union workplaces: of those who report that their managers favour unions, a markedly greater proportion would join a union if one were available (51.7 percent) than is the case for those who report that their managers are opposed to unions (31.9 percent).

The EC Act was repealed by a new Labour Government in 2000, and replaced by the Employment Relations Act (ER Act), a piece of legislation somewhat more supportive of unions. The ER Act acknowledges unions, and provides them with some rights in employment relationships, notably bargaining agent exclusivity in collective negotiations. However, individual bargaining still remains the predominant pattern, and since the introduction of the ER Act union density and collective bargaining have increased only marginally. One possible reason that union density has not increased greatly is that, in the private sector at least, nearly 50 percent of workers felt indifferent or sceptical towards unions, seeing them "as making no difference to their personal interests or making things worse" (Haynes et al., 2006:212).

The employment relations climate created by the EC Act throughout the 1990s, and the relatively weak counter-response of the ER Act, will have impacted both managerial and worker views towards employment relationships in New Zealand, with the mindsets of both these groups being conditioned by the unitarist ideology of the EC Act. 


\subsection{Human Resource Management - A Unitary Model of People Management}

Human Resource Management (HRM) is a broad term which has come to represent the suite of management practices used strategically by an employing organisation (Boselie, Dietz and Boon, 2005) to shape and develop the employment relationship so as to maximize organisational success.

It is widely considered that effective HRM practices can engender desirable attitudes amongst the workforce. Increased worker satisfaction and commitment to the organisation are the desired results. Indeed enhancing worker commitment is seen as pivotal to organisation performance. For example, Whitfield and Poole (1997:746) claim "good organisational performance is increasingly seen to be fundamentally dependent upon the commitment offered by the workforce". These attitudes have an effect on employee behaviour, which in turn positively impacts performance of either the individual or even the work unit, dependent on the mode of structuring work used. This improved performance, in turn, benefits the organisation (Edwards and Wright, 2001) by enhancing its economic returns (Pfeffer and Veiga, 1999).

A range of best practices in HRM aimed at achieving this goal have been identified in the literature (Delery and Doty, 1996; Pfeffer, 1994; Arthur, 1994). While there are some slight differences in the practices identified by different authors in the best practice literature, there are also many similarities amongst them (see for example, the work of Paauwe and Richardson, 1997; Delery and Doty, 1996; Pfeffer, 1994; and Huselid, 1995). In general 'best practice' HRM encompasses the functional areas of training and development, employee selection, communication, performance appraisals, and teamwork.

'Best practice' in HRM tends to be associated with a unitarist view of the employment relationship. This is because its primary goal is to promote mutuality (Legge, 1995) - mutual goals, influence, respect, rewards and responsibility, for example (Walton, 1985). The theory is that policies of mutuality will elicit in the workforce commitment and motivation towards the organisation. These in turn are said to yield both better economic 
performance and greater employee development, hence providing the organisation with a competitive advantage (Kinnie, Purcell, and Hutchinson, 2000).

Despite these desirable performance and attitudinal outcomes supposedly obtained from the implementation of best practice HRM, studies consistently find take-up of these practices to be low (Edwards and Wright, 2001). Two possible constraints that serve to impede usage of 'best practice' HRM have been identified. The first is the 'atmosphere of current employment relations' and, the second is 'whether there is a union present at the workplace' (Whitfield and Poole, 1997:748). There are mixed research indicators of union impact. For example, some studies find that union presence (Ackers, Smith and Smith, 1996), coupled with effective communication mechanisms can assist the introduction of best practice HRM (Eaton and Voos, 1989). Others show that some unions are hostile to the introduction of 'best practice' HRM (Guest, 1995). Indeed the interests of unions are often considered to be antithetical to the objectives pursued under a best practice HRM model, unions being seen as competitors with the employing organisation for the commitment of the workforce.

This exploratory paper attempts to examine these issues, and to an extent fill some of the gaps identified in the literature, by reporting views about employment relationships obtained from a group of New Zealand managers and workers.

\section{THIS STUDY}

The objective of this paper is to articulate and analyse views about employment relations gathered from a sample of managers and workers. Data used for this study were collected as part of a larger study which sought both quantitative and qualitative responses. This paper reports mainly qualitative data, however with quantitative data included where appropriate and useful to the discussion. The views presented came as open-ended responses included in a questionnaire designed to measure any associations between employment relations values and beliefs, perceptions of high commitment management practices, and organisational commitment. Specifically, at the end of the 
questionnaire a broad statement was included that read "This survey may not have covered some aspects of the employment relationship that you consider important. If you have any strong views (positive or negative), please feel free to write them here". Comments were invited under four broad headings: (1) employment relations in general; (2) employment relations at your organisation; (3) the management at your organisation; and (4) the workforce at your organisation.

\subsection{The Sample}

A total of 1212 respondents (manager sample $n=792$; non-managerial worker sample $n=420$ ) participated in the original study (see Geare et al., 2006) by completing the survey. The population was taken as organisations from the four main centres: Auckland, Wellington, Christchurch and Dunedin, listed in the New Zealand Business Who's Who (2004). The sample was every third organisation with 25 or fewer employees, along with all organisations with over 25 employees. Of these, 202 individual respondents chose to comment in relation to one or more of the four headings provided. A total of 583 comments were received in all. These comments were content-analysed using a thematic-coding approach (Flick, 2002) to identify recurrent themes (Easterby-Smith, Thorpe and Lowe, 1991). These recurrent themes can then be related to relevant theory, and it is this format that comprises the framework for presentation and discussion of the data.

\subsection{Data Analysis}

This is an exploratory study describing the views New Zealand managers and non-managerial workers have about employment relationships. Qualitative data were coded to reflect identifiable recurring themes. Responses were also classified into the two respondent groups - managers and workers. The themes/issues identified appeared to fall into two distinct categories - (1) normative views about the nature of employment relations; and (2) opinions concerning functional practices. The former group specifically comprises respondent comments relating to organisational objectives, unions, trust, loyalty, and competency issues. The latter group comprises respondent views about the ways in which HRM is being 
practised or implemented. Views on functional aspects of HRM, including recruitment and selection, compensation, the use of teamwork as a mode of structuring work, training and development, employment security, communication, and fairness and uniformity in terms and conditions of employment were evident.

Related quantitative data, as stated previously, came from a survey examining employment relations values and beliefs. In this survey respondents were asked to indicate, using a five-point Likert scale, their views on (a) management/worker employment relations (i) in general and (ii) in their own workplace; (b) the effectiveness of current HRM policies and practices in their workplaces (using two statements adapted from the work of Tsui (1990); (c) the extent to which they shared, and worked towards, the goals and objectives of their organisation (adapted from a measure of employment relations ideology developed by Geare (1986); and (d) levels of organisational commitment (measured using three items adapted from the scale $(a=$ 0.77) developed by Mowday, Steers and Porter (1979). Quantitative data reported here is for the total survey sample (i.e. 1212 participants).

\section{FINDINGS}

This paper aims to provide an account of how managers and workers currently view employment relationships. The specific themes noted above are now used as the framework for the presentation of theory and data, and for the subsequent discussion.

\subsection{Normative Views on Employment Relations}

A high level of organisational commitment among the workforce supposedly delivers specific HR outcomes, including employee retention (turnover), and desirable job-behaviours such as increased performance and reduced absenteeism (Sommers, 1995). Organisational commitment can be defined in terms of the nature of the relationship. Some suggest it is reflected in employee loyalty to the employer, as well as in integration of individual and organisational goals (see, for example, Paul and Anantharaman, 2004). Thus, an intended 
outcome of best practice HRM initiatives aimed at fostering the development of shared objectives between management and workers is enhanced organisational commitment. This paper first presents data pertaining to shared organisational objectives, and then examines the related concept of organisational commitment.

\subsubsection{Organisational Objectives}

As noted, the attainment of a shared values and beliefs system between management and workers, especially in terms of the organisation's goals, is seen as one of the primary outcomes resulting from 'best practice' HRM. Respondent views obtained in this study suggest managers and workers are cognisant of this intent and aspire to achieve a situation where mutually developed and accepted goals are established and pursued. For example:

... committed to the mission. Get on well at meetings and seminars finding common ground to advance the effectiveness of our workplace employment.

However, there is also ample evidence indicating attainment of this type of congruence, while intuitively appealing and idealistic, is hampered by the self-serving interests of one, or other, of these two groups. For example, a manager respondent claimed:

Generally speaking, employment relations in the company are very good. It is usually self-serving behaviour which is the source of a conflict.

On the other hand, typical of the types of responses received from workers is the following sentiment:

Management needs to be one that isn't individual focussed so that nonmanagement members feel inferior to their supervisors. We all know that there are hierarchical systems in all businesses but everyone should be aiming towards the same goal within the organisation. 
However, some workers held the view that the goals of the organisation were not shared by all:

I believe most employers are interested in their own interests not their workers'. They want to pay as little as possible to workers and not pass on any profits to employees.

Management's too goal oriented and are not giving people enough praise or opportunities to grow. They seem to be trying to enforce their views instead of cooperation and encouragement.

Yet others indicated pursuit of mutual goals was a reality:

The workforce work with management to achieve all goals that are set.

A barrier to the development and pursuit of mutual goals within the employment relationship identified by workers was a perception of an "us and them" mentality prevailing in the organisation. Interestingly, some employees believe this is created by management - not by unions or "employee troublemakers" as conventional unitarist thinking would suggest. Typical of the worker responses are the following:

Some managers are creating an "us and them" mentality with some workers. It is a shame that some managers are very strong but the actions of others affect the whole company.

Management in my organisation need to put some strategy in place on how to bring together managerial and non-managerial staff. At the moment we have a them and us kind of relationship

Management and worker have big gaps and it is made clear not to cross the line; as far as pursuing a matter of importance to the workers, you never win.

The company has supposedly taken on a policy of valuing its employees. The way the staff at ... have been treated (as well as previous closures) goes against these values. The employees expectations haven't been met and the goal posts are continually moved to suit the company at the time. 
Survey data exploring manager and worker respondents' views on shared objectives shows managers $(M=3.80$, s.d. $=0.906)$ tend to agree more strongly than do workers $(M=3.35$, s.d. $=1.205)$ with the statement,"In this organisation, staff members share the overall goals of management and willingly work towards achievement of these goals". The mean difference between these groups is statistically significant $(t=$ 7.166, $p<0.000)$.

\subsubsection{Commitment}

A high level of commitment amongst the workforce is important in the HRM scheme of things. Worker commitment to the organisation is believed to foster workforce behaviours which are primarily selfregulated, as opposed to being controlled via external means such as managerial authority (Walton, 1985).

Organisational commitment can be defined as "the relative strength of an individual's identification with and involvement in a particular organization" and it is characterised by three related factors "(1) a strong belief in and acceptance of the organization's goals and values; (2) a willingness to exert considerable effort on behalf of the organization; and (3) a strong desire to maintain membership of the organization" (Mowday, Steers and Porter, 1979:226).

The qualitative data obtained in this study identified commitment as an isolated theme. Responses from managers, not surprisingly, reiterated the view that they had a strongly committed workforce. For example, one manager claimed "a truly excellent group of people with an unusual commitment to the success of the organisation". Responses from workers, however, provided an extreme range of views about commitment, with some claiming to be " $100 \%$ committed to my company," while others acknowledged that they had "no commitment" to the company.

Commitment was judged from responses to survey questions aimed at revealing three dimensions of commitment: attitudinal, behavioural and continuance. The responses shown in Table One indicate that, compared to the worker group, the manager group was statistically significantly more committed to the organisation across all three dimensions. 
Table 1: Levels of Organisational Commitment ${ }^{\nabla}$

Attitudinal Commitment

$\begin{array}{ll}\text { Managers } & \text { Workers } \\ \text { Mean*(s.d.) } & \text { Mean(s.d.) }\end{array}$

"I nearly always agree with this organisation's policies on important

$4.08(.829)$

$3.53(.884)$

matters relating to its employees"

Behavioural Commitment

"My work environment allows me to contribute to my full potential"

$4.09(.964)$

$3.54(1.182)$

Continuance Commitment

"I intend to stay working for this organisation for a long time"

* $\quad$ Scale: 1 = Strongly Disagree to $5=$ Strongly Agree

$\nabla \quad$ All group differences statistically significant at the .001 level

\subsubsection{Trust and Loyalty}

A further theme raised by the worker group was "trust and loyalty" in the employment relationship. Workers conveyed a strong message that they lacked trust in management. This appears to mainly stem from cases in which workers perceive they have been misled or betrayed, and management lacked loyalty to them. This theme clearly is interrelated with the previous two, as without trust and perceived loyalty, it is unlikely that high levels of commitment and mutually accepted goals can be developed.

There is increasing distrust of management as wages remain very low. There needs to be more actual recognition of skills rather than token words.

The management are not ideal. They tell you one thing and do another. The lies are often and hurtful. Also they can't be trusted. Any thing that is promised has to be taken with a "grain of salt" or written down and signed by them so you can prove what they have said.

Some workers also do not appear to have developed high levels of loyalty to the organisation. Responses typifying this situation include: 
The pride and professionalism of the workers is what keeps the company going, certainly not loyalty to the company. Eventually the goodwill will wear out and the company will find itself in a compromising position. Why don't they learn!

Younger people do not seem to have much loyalty to their employer. As one said to me "I can get $\$ 110$ on the dole, therefore I'm working for only $\$ 220$ p/week. Why should I break my back?" I don't know of any way to get this person to do a reasonable day's work.

Some managers achieve success through what appear to be effective approaches to communicating with the workforce:

One first class manager at the top maintains the loyalty of staff and ensures the success of the operation by keeping his door open to all.

Only one manager commented on the subject of loyalty, but the response is worth reporting as it shows cognisance and awareness of the worker view:

It is my feeling that modern employment relations does nothing to encourage a feeling of loyalty to an employer. In fact it has created a real us and them mentality where workers feel they must look out for number one because the organisation won't.

\subsubsection{Employment Relations in the Workplace - The Role and Performance of Unions}

One of the main problems facing unions today is that commitmentfocussed models of HRM, such as the best practice model, are underpinned by the assumption that unions are antithetical to effective people management. Management opposition to unions stems from the belief that the two are in competition for worker loyalty. This study finds evidence to suggest that this assumption does indeed have currency among some managers: 
Unionised in significant areas which sometimes leads to a greater loyalty to the craft rather than the organisation. Management and unions are getting better at communication on key issues.

Highly skilled and committed to the job. Perhaps 20 percent are more loyal to craft/union, than to the organisation.

The role and performance of unions were issues consistently raised by managers and workers. Views differ markedly between the two groups. As far as managers were concerned, unions were seen to be too adversarial, and some considered them unnecessary. The following comments are generally reflective of the manager subsample:

I feel the role of unions in employment relations in New Zealand is still generally seen from a 19th century view. Their role is still subject to major change depending on the parties in political power and on agendas that are not completely clear before elections. Generally the role of unions in NZ seems to me to be seen as too adversarial and they are not given sufficient means and power to understand and influence the organisations and their members belong to.

We have a union free site. Unions have failed to convince workers at this site that they offer workers an advantage. Relations determined by cultural pit. Our organisation is undergoing a transition to a more collaborative culture-not quite there.

I think that the changes in law of the last two years are now too much in favour of the union/employee. We've gone too far!

There were a few exceptions to these views, indicating some managers were in the process of, or had already, established effective management/union partnerships:

This employer is not paranoid about dealing with unions and achieving collective employment contracts. In many respects this company has an enlightened attitude to employment relations ... 
The worker group offered a somewhat different picture to management about the role of unions and their effectiveness. Many see unions as being integral to the establishment of desirable working conditions and terms of employment:

Modern unions have become more professional and better involve their membership.

New Zealand appears to be changing from a period of benign unions/high company growth, to a period where employees will demand a more equitable distribution of wealth.

Wage increases have been lagging behind cost of living. There will be a time when this needs to be sorted. Unions are needed more than ever now.

[Employment relations] are improved significantly by the actions of my union. Management are not trained well though in their jobs. They get little support from above and have little success dealing with staff.

Without a strong union, many New Zealand employees probably aren't being rewarded in their line of work, despite most companies doing well in current and recent economic boom.

Workers also appear very cognisant of management attempts to alienate or obstruct union membership and performance. For example:

In general employees should not have to choose between joining a union or being thrown to the mercy of the employer.

Management distrust the unions, and the unions distrust the management.

Management only consult the union and staff generally if they are legally required to. 
I feel our company does not like union involvement of it's staff as they find these people difficult to reach agreement with compared to non union members. Union involvement is not encouraged by the company or ever mentioned actually.

Have been bad in the past, but have improved in recent years. Still not convinced that there is a genuine intent to include the union in full consultation regarding work practises ...

Some local management care more about the bottom line (profits) than the staff. Concern HR meddle too much in some staff matters would be good to have a neutral HR instead of pro company/anti union. (maybe in an ideal world) $\cdots$

But, a number of workers also expressed dissatisfaction with current union performance:

I have never had a good experience with a union. The ones I have been a member of or worked with are self-serving and not interested in individuals. Try to justify their own existence. Sad.

I find our union representatives frustratingly negative. They often are found searching for a non-existent (management) hidden agenda. I would like to see our union become more positive.

Survey data rating management/worker relations found that, at the national level, managers $(\mathrm{M}=3.14$, s.d. $=0.611)$ and workers $(\mathrm{M}=$ 3.03 , s.d. $=0.687$ ) held very similar views (with $1=$ Very Poor and $5=$ Very Good). However, this did not extend to views at the workplace level, where the manager group $(M=4.19$, s.d. $=0.810)$ tended to report a more favourable view of the current climate than did the worker group $(\mathrm{M}=3.84$, s.d. $=1.006)$. This difference being statistically significant $(t=6.527, p<0.000)$. 


\subsubsection{HRM Competency and Role Issues}

During data analysis it became very obvious that by far the greatest number of comments made, by manager and worker respondents in this study, were targeted towards the issue of 'competency' and in particular 'competency' of the HRM function. Comments received were both positive and negative. The bulk of the negative responses concerned a lack of consistency in the application of HRM policies and a perceived gap between policy rhetoric and policy implementation. These views are consistent with those found in a previous study on New Zealand employee views towards HRM (Browning and Edgar, 2004).

HR need to practise what they preach to include everybody. An example of this is when one employee is treated differently to another, on a similar case.

HRM here is not as good as it could be. There is a certain amount of "goal post" moving and job creation on their part. Rules are manipulated to suit certain members ...

HRM sometimes pay lip service to what should be good practices. Performance reviews are an example of this - carried out across the board annually but for most people they result in no changes. May be due to underresourcing of HRM team.

The positive responses, on the other hand, suggest HR professionals in New Zealand tend to be actively engaging in the role of employee champion (Ulrich, 1997), and establishing more effective channels of communication with workers. This suggests a reversal of the trend found some years ago in the study by Browning and Edgar (2004).

Are very respectful and supportive of us.

For the most part exceptional - a superb group of people.

Not all shared this view, though: 
Still suspicion that HR section working for management rather than organisation as a whole.

Appear to be driven by cost benefit for senior management with little time spent on the benefits/costs for the employees.

Are good honest people of integrity caught between making ok pragmatic business decisions which may not be in the best interest of staff.

HR should be renamed 'People Dept' to remind HR people that we are more than a 'resource'.

Survey data pertaining to the HRM function within organisations revealed that while both managers and workers tended to be reasonably satisfied with HRM performance, the manager group again tended to rate HRM performance more highly than did the worker group. Responding to the statement "Overall, to what extent do you feel HRM policies and practices in your workplace are performed the way you would like them to be performed?" the mean for the manager group was 3.53 (s.d. = 0.907), and the mean for the worker group was 3.25 (s.d. = 1.037) $(t=4.844, p<0.01)$. A similar difference is found in responses from managers $(M=3.52$, s.d. $=0.905)$ and workers $(M=$ 3.18 , s.d. $=1.070)$ to the statement "To what extent has the HRM function in your workplace met your expectations in its human resource management roles and responsibilities?" $(t=5.921, p<0.001)$.

\subsection{Functional HRM}

A number of respondents chose to make comments on the ways HRM is practised in their organisations. This section briefly discusses their views across the functional HRM areas of recruitment and selection, communication, employment security, training and development, teamwork, and compensation. 


\subsubsection{Recruitment and Selection}

Eleven respondents chose to comment about recruitment and selection and most of these were from the manager group. In general the responses indicated managers found it difficult to find "good staff" with the right skills for vacant positions. Consistent with HRM philosophy there is evidence to suggest managers place an emphasis on hiring only those people who "fit" with the culture of the organisation - the reason given for this is that it helps to protect the status quo. The few workers' views provided expressed concern about lack of transparency in the recruitment and selection process.

\subsubsection{Communication and participation}

Models of people management that rely on control can be seen to foster alienation of the workforce, thus reducing labour productivity. On the other hand, activities that promote commitment and satisfaction by enabling workers to have some control over, and involvement in the work process (Whitfield and Poole, 1997) are considered to lead to improved performance. Opportunities to participate in decision-making within the organisation, along with the use of team work as the mode for structuring work are examples of 'high involvement' work practices and the broad area of communication is the domain under which these practices can be classified.

A significant number of respondents (43) expressed views about communication and participation. The manager group appeared aware of communication breakdowns and identified this as being an area for improvement, while the worker group generally cited incidents of communication breakdowns. Notably, the workers consider the breakdowns to most often occur at the middle-management level, not upper-management.

As Table Two indicates, the managers are significantly more likely than the workers to say that they can participate in decisions that affect them. Views on team briefing sessions, however, are very similar between the groups. 
Table 2: Opportunities for communication and Participation in Decision-making

\begin{tabular}{|c|c|c|c|}
\hline & \multicolumn{2}{|c|}{ Managers } & Workers \\
\hline & Mean & (s.d.) & Mean (s.d.) \\
\hline $\begin{array}{l}\text { "I am provided with opportunities to } \\
\text { participate in workplace decisions that } \\
\text { affect me". }\end{array}$ & 4.18 & $(0.894)$ & $\begin{array}{l}3.13 \quad(1.390) \\
(p<.001)\end{array}$ \\
\hline $\begin{array}{l}\text { "Planned team briefing sessions are } \\
\text { regularly held for staff members in the } \\
\text { organisation". }\end{array}$ & 3.58 & (1.226) & $\begin{array}{l}3.42 \quad(1.142) \\
(p<.05)\end{array}$ \\
\hline
\end{tabular}

* Scale: 1 = Strongly Disagree to $5=$ Strongly Agree

\subsubsection{Teamwork}

A related initiative supporting high involvement work practices within an organisation is teamwork. Nearly all respondents, both managers and workers, who commented on teamwork expressed positive sentiments about this mode of structuring work. An example from a worker typifying these responses is, "We all work together as a team to achieve our goals and we all work really well together". This mode of structuring work seems prevalent in the workplace with both manager $(M=3.91$, s.d. = 1.035) and worker $(M=3.66$, s.d. = 1.209) respondents reporting a moderate to high incidence of its usage. Even though the difference between these means is found to be statistically significant, the actual size of this perceptual difference is small. No difference in mean perceptions is found for the usage of quality circles, however, with managers $(M=3.48$, s.d. $=1.284)$ and workers $(M=3.50$, s.d. $=1.460)$ both reporting moderate usage.

\subsubsection{Employment Security}

All the comments concerning employment security came from the worker group. The general theme was a perception that management considers workers easily dispensable, and the negative impact this perception had on attitudes towards the organisation. The quantitative 
survey data support these comments. When responding to the statement, "This organisation protects the security of its core workforce by employing temporary staff members only when absolutely necessary," the mean for the manager group $(M=4.04$, s.d. $=1.169)$ was far higher than that for the worker group $(M=3.20$, s.d. = 1.646), confirming that managers strongly agree with this statement. This difference in views is, again, both substantial and statistically significant $(t=10.195, p<0.000)$.

\subsubsection{Training and Development}

A number of responses related to training and development and these were evenly distributed across the manager and the worker subsamples. Virtually without exception, the manager responses highlighted programmes, policies and initiatives that had been established to ensure workers received training and developmental opportunities. Nonetheless, the worker responses generally indicated that not enough was being provided along these lines.

\subsubsection{Compensation}

The largest number of comments received about HRM practice related to compensation (51 in total). Both the manager and worker groups expressed concern about 'poor pay,' managers claiming they could not offer more, workers indicating they wanted more. Salary reviews were considered by several workers to be a "waste of time" and bonus systems that were not applied to all staff also attracted cynicism. While no survey statements directly targeted compensation per se, one statement did examine processes that ensured consistency and uniformity across terms and conditions of employment for all staff. This is a practice which is designed to encourage wage compression and remove potential status barriers between levels of staff working within the same organisation. 


\section{DISCUSSION}

The views expressed by managers and workers reported in this study have direct parallels with many of the issues raised in the Employment Relations and HRM literature. Two identifiable areas emerged from an examination of the data. One group of data can be specifically characterised as relating to the broader employment relationship, while a second appears more related to specific functional aspects of HRM practice. The findings across these two areas are now discussed.

First, as far as the broader employment relationship is concerned, there is evidence to indicate that managers embrace the unitarist underpinnings of HRM - that is, that shared goals among organisational members are necessary for effective employment relations. Workers, on the other hand, seem to acknowledge that, while this may be a goal of management, it is not necessarily a realistic one. It often, they say, leads to self-serving behaviour by managers and ignorance of worker interests. There are, nonetheless, moderate levels of support from both managers and workers for the HRM claim that management and workers share the same organisational goals, and willingly work towards them.

A theme related to the HRM goal of shared objectives in the employment relationship is the desirable and consequential outcome of organisational commitment. Views from managers and workers on this topic were mixed. Manager feedback suggested high levels of commitment among their workforces, while the views of workers offered a more diverse picture of reality. The quantitative data is instructional here in interpreting these mixed messages. It clearly conveys that managers are more committed to their organisations than are their workers, and thus they may well have a more optimistic view of their workers' commitment than is actually the case.

Both the notion that the goals of managers and workers are shared goals, as well as initiatives aimed at eliciting high levels of commitment within the workforce, run counter to the pluralist ideas that underpin unions. Thus these two factors give rise to claims that unions are antithetical to HRM, and arguably these are important factors impeding the development of effective union-management partnerships. Clear evidence is found to support the notion that the goals of HRM conflict with those pursued by unions, thus promoting the view that unions are unnecessary. 
Two primary reasons for keeping unions out of the workplace are cited by managers. The first is that unions remain too adversarial. The second is that unions are seen to compete with the organisation for worker commitment, and thus their presence is deemed disruptive. Workers appear cognisant of management attempts to obstruct union membership, and many see unions as necessary if workers are to maintain adequate terms and conditions of employment.

However, competency of the HRM function was the topic that attracted by far the greatest number of responses - both positive and negative. A lack of consistency in the application of HRM policies and practices emerged as a common negative theme, whereas strong employee championing by HR staff was identified as a positive theme. Managers and workers both moderately approved the performance of the HRM function in their organisations, with managers tending to be more favourable than workers.

The second identifiable theme emerging from the data pertains to functional areas of HRM practice - specifically, recruitment and selection, communication, teamwork, employment security, training and development and compensation. Effective implementation of HRM practice across these areas is seen as important, because research suggest that their effective use has substantial and positive benefits in the financial performance of the organisation (Huselid, 1995).

Evidence obtained suggests managers do attempt to hire for 'fit' within their organisations, thus supporting the earlier finding that, for management, development and pursuit of shared goals is an objective of HRM practice. A further issue raised by managers was the inability to find 'good' staff. This comment is supported by a number of New Zealand studies and official statistics that suggest the country is experiencing a 'brain drain,' with many of the young, educated workforce heading overseas to gain employment.

When it comes to communication, managers recognise this as an area where they 'could do better'. One of the main factors resulting in communication breakdowns, identified from the worker perspective, is middle management not passing on information. This was not seen to be caused by upper management. Unsurprisingly, managers appear to receive far more opportunities to participate in decision-making within their organisation than do their workers. However, there is a considerable gap between managers' perceptions of their workers' opportunities to participate in decision-making, and what workers themselves reported in that respect. 
Teamwork seems to be the prevalent mode of structuring work within the organisations participating in this study, and both managers and workers appear to be happy with this arrangement.

Workers expressed concern about the lack of employment security in their workplaces, and this concern was reiterated by the survey data. Indeed managers projected a much more optimistic view of their attempts to promote employment security than that perceived by workers.

Managers indicated a number of training and developmental opportunities that were being offered to workers, while workers commented that this was still not enough. The survey data offered a somewhat different, yet not necessarily contradictory picture. It revealed that both managers and workers consider more importance is placed on the training and development of the worker group, as opposed to the manager group. However, when coupled with the views expressed by workers, it seems that while training is deemed important, still not enough opportunities are being made available to satisfy workers.

Again unsurprisingly, compensation appears to be an issue that is on the top of the minds of both managers and workers. Both groups expressed a desire for higher pay. The workers complained of 'poor pay', while the manager group claimed they could not afford to increase the organisation's labour costs. Apparently, the thrill of meeting organisational objectives remains insufficient reward for many workers.

\section{CONCLUDING REMARKS}

This paper has identified a number of areas where it would seem that the employment relations views of managers, and to a lesser extent, workers have been shaped in a unitary fashion. Some of this could be attributed to a regulatory framework that enables, or even fosters, this sort of identification. Alternatively, it could have derived from constant exposure to a model of people management which strives to promote in the workforce a strong identification with the goals of the employing organisation.

This being said, there is also a strong, residual element of pluralism evident in worker views. There is a fairly widespread recognition that unions have something to offer the workforce, maybe not in terms of enhancing conditions of employment, but certainly in the defensive sense of maintaining the status quo, and avoiding further slippage. 
Indeed, part of this 'perceived need' by workers for union presence may stem from the worker view that managers are overtly adopting strategies of union avoidance. Nevertheless, some managers are aware of workers' perceived need for unions, and many appear willing to maintain relationships with unions. The preferred nature of this relationship, however, is co-operative rather than adversarial.

Attempts at implementing best practices in HRM are evident in many of the organisations participating in this study. Some practices seem to have been effectively implemented, although both managers and workers identify areas that require improvement.

On a positive note, the 'employee champion' role seems to have been embraced by many working within HRM. The downside is that, despite being recognised as pivotal to effective management of people, communication between management and the workforce is seen by many as being done poorly, and as an area of management practice that needs to be remedied.

Perhaps the most important message for employing organisations emerging from this research is that managerial 'competence' in performing HRM functions is, as far as workers are concerned, requisite to its perceived success. This means that organisations need to expend the effort to equip their HRM staff with the necessary knowledge, skills and attitudes to do the job properly, and that if they do so, positive workforce benefits are likely to result. 


\section{REFERENCES}

Ackers, P., C. Smith and P. Smith. (1996). The new workplace and trade unionism, London, Routledge.

Adams, R. (1989). North American industrial relations: Divergent trends in Canada and the United States, International Labour review, 128(1): 47-64.

Adams, R. (1999). Why statutory union recognition is bad labour policy: the North American experience. Industrial Relations Journal, 30(2): 96-100.

Adams, R. (2002). The Wagner Act Model: A Toxic System beyond Repair. British Journal of Industrial Relations, 40(1): 122-127.

Arthur, J. (1994). Effects of human resource systems on manufacturing performance and turnover. Academy of Management Journal, 37(3):670-687.

Boselie, P., G. Dietz, and C. Boon, (2005). Commonalities and contradictions in HRM and performance research. Human Resource Management Journal, 15(3):67-94.

Boselie, P., J. Paauwe, and R. Richardson. (2003). Human resource management, institutionalization and organizational performance: a comparison of hospitals, hotels and local government. International Journal of Human Resource Management, 14(8):1407-1429.

Brown, W., S. Deakin, D. Nash and S. Oxenbridge. (2000). The Employment Contract: From Collective Procedures to Individual Rights. British Journal of Industrial Relations, 38(4): 611-629.

Browning, V. and F. Edgar. (2004). Reactions to HRM: An Employee Perspective from South Africa and New Zealand. Journal of the Australian and New Zealand Academy of Management (JANZAM). 10(2):1-13. 
Delery, J. and D. Doty, D.(1996). Modes of theorizing in strategic human resource management: Tests of universalistic, contingency, and configurational performance predictions. Academy of Management Journal, 39(4): 802.

Easterby-Smith, M., R. Thorpe, and A. Lowe. (1991). Management Research: An Introduction. London: Sage Publications Ltd.

Eaton, A. and P. Voos. (1989). The ability of unions to adapt to innovative workplace arrangements, The American Economic Review. 79(2):172-176.

Edwards, P. and M. Wright. (2001). High-Involvement Work Systems and Performance Outcomes: The Strength of Variable, Contingent and ContextBound Relationships'. International Journal of Human Resource Management, 12(4):568-585.

Flick, U. (2002). An Introduction to Qualitative Research, Sage Publications, London, UK.

Geare, A. (1986). An Examination of certain aspects of Industrial Relations ideologies: A theoretical analysis and an empirical Study, PhD thesis - 87 30270, University of Otago, New Zealand.

Geare, A. Edgar, F. and McAndrew, I., (2006). Employment Relationships: Ideology and HRM Practice, International Journal of Human Resource Management, 17(7):1190-1208.

Godard, J. and J. Delaney. (2000). Reflections on the "high performance" paradigm's implications for Industrial Relations as a field. Industrial and Labor Relations Review, 53(3): 482-502.

Guest, D. (1995). Human resource management, trade unions and industrial relations. In J. Storey (Ed.), Human resource management: A critical text (pp. 110-141). London ; New York: Routledge.

Guest, David E., (1999). Human Resource Management - The Worker's Verdict, Human Resource Management Journal, 9(3):5-25. 
Guest, David. E., (2001). Human Resource Management: When Research Confronts Theory, International Journal of Human Resource Management, 12(7):1092-1106.

Haynes, P., P. Boxall and K. Mackay. (2006). Union reach, the 'representation gap' and the prospects for unionism in New Zealand, Journal of Industrial Relations, 48(2):193-216.

Holgate, J., E. Hebson, and A. McBride. (2006). Why gender and 'difference' matters: A critical appraisal of industrial relations research, Industrial Relations Journal, 37(4):310-328.

Legge, K. (1995). Human Resource Management: Rhetorics and Realities. London: Macmillan.

Mowday, R., M. Steers, and L. Porter. (1979). The measurement of organisational commitment, Journal of Vocational Behavior, 14:224-247.

New Zealand Business Who's Who. (2004), Auckland: New Zealand Financial Press Ltd.

Paul, A and R. Anantharaman. (2004). Influence of HRM Practices on Organisational Commitment: a study among software professionals in India. Human Resource Development Quarterly, 15 (1):77-88.

Pfeffer, J. (1994). Competitive Advantage Through People: Unleashing the Power of the Work Force. Boston: Harvard Business School Press.

Sommers, M. (1995). Organisational commitment, turnover and absenteeism : an examination of direct and interaction effects. Journal of Organisational Behavior, 16, 49-58.

Tsui, A. (1990). A multiple-constituency model of effectiveness: An empirical examination at the human resource subunit level, Administrative Science Quarterly, 35(3):458-484. 
Ulrich, D. (1997). Human Resource Champions: The next agenda for adding value and deliver results. Boston: Harvard Business School Press.

Walton, R.E. (1985). From Control to Commitment in the Workplace. Harvard Business Review, 63 (2):76-85.

Whitfield, K. and M. Poole. (1997). Organizing employment for high performance: Theories, evidence and policy, Organization Studies, 18(5):745764. 